\title{
ON THE CLEAVAGE OF AMPHIBIAN OVA.
}

\author{
E. O. JORDAN AND A. C. EYCLESHYMER.
}

Our observations upon the early cleavage stages of several sorts of amphibian eggs were made primarily with a view to determining the extent and frequency of cleavage variation. The eggs examined were those of two species of Urodela, Amblystoma punctatum and Diemyctylus viridescens - and two Anura, - Rana palustris and, Bufo variabilis.

The unsegmented eggs of Amblystoma were usually collected before eight o'clock in the morning, and began to segment at three or four o'clock on the afternoon of the same day. As we hope to show presently, there is reason to believe that there is an interval of nearly ten hours between the laying of the eggs and the appearance of the first furrow ; these eggs, therefore, were probably laid at about five or six o'clock in the morning. Other bunches of Amblystoma eggs were in the early stages of cleavage when collected in the morning, and these were undoubtedly deposited on the preceding evening. Clarke ('80) states that most of the eggs laid by the Amblystoma in his aquaria "were laid during the night, and by nine o'clock the next morning the first segmentation furrow had usually made its appearance."

The eggs of Diemyctylus are best obtained from females in captivity, and can be removed from the membrane as soon as laid (Jordan, '93, p. 275 et seq.). The first cleavage furrow appears about ten hours after laying. ${ }^{1}$ Since there is a close correspondence in all other time phenomena between the egg of the newt and the egg of Amblystoma, we are justified in

1 Born (Anat. Ans. VII, 189z, p. 809) refers to a paper by Grönroos, which we have, unfortunately, been unable to see (Ueber die Eifurchung bei den Tritonen. Diss. inaug. Helsingfors, I89o). According to Born, Grönroos has shown "dass bei gewöhnlicher Zimmertemperatur die erste Furche an reifen Tritoneiern 5-6 Stunden nach der Besamung auftritt - gemeint sind natürlich Uteruseier - im Gegensatz zu den Eiern unserer einheimischen Anuran bei denen unter gleichen Bedingungen der Eintritt der ersten Furche nach 3 Stunden erfolgt." 
concluding, as we have already intimated, that in this respect also, there is time agreement, and that the eggs of Amblystoma, as well as those of the newt, begin to segment about ten hours after they are laid.

The eggs of Rana and Bufo may be found unsegmented in the ponds in the early morning. The first furrow appears, as a rule, earlier in the day than it does in Amblystoma. We did not particularly question this point, however, since Newport (Phil. Trans. 1851, 1853, I 854) long ago determined that the frog's egg begins to segment in from four to five hours after the spermatozoa are applied. Our own incidental observations upon the eggs of the frog and toad amply confirm this result.

All the eggs when brought to the laboratory were put under uniform conditions - in shallow dishes of water at about $18^{\circ} \mathrm{C}$. The cleavage stages were followed in the living egg with the aid of the Zeiss dissecting microscope. A plane mirror placed underneath the flat and thin-walled glass dish in which the egg rested enabled us to observe accurately the progress and position of the furrows in the lower hemisphere.

The exact time of appearance of each set of furrows was noted in all cases, and is recorded on most of our figures. The following table expresses this record in a condensed form, the times given for the inter-cleavage periods representing the average of our observations on some fifteen to twenty eggs in each stage. ${ }^{1}$

\begin{tabular}{|c|c|c|c|c|}
\hline & Amblystoma. & Rana. & Diemyctylus. & Bufo. \\
\hline $\begin{array}{l}\text { Interval between fertilization and xst cleavage. } \\
\text { Interval between } x \text { st and } 2 \text { d cleavages . } \\
\text { Interval between } 2 \mathrm{~d} \text { and } 3 \text { d cleavages } . . \\
\text { Interval between } 3 \text { d and } 4 \text { th cleavages. } \\
\text { Interval between } 4 \text { th and } 5 \text { th cleavages. } \\
\text { Interval between } 5 \text { th and } 6 \text { th cleavages. } \\
\text { Interval between } 6 \text { th and } 7 \text { th cleavages. } \\
\text { Interval between } 7 \text { th and } 8 \text { th cleavages. } \\
\text { Interval between } 8 \text { th and } 9 \text { th cleavages. } \\
\text { Interval between } 9 \text { th and roth cleavages .. }\end{array}$ & 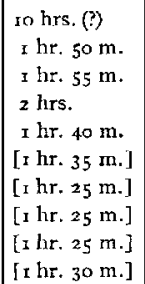 & 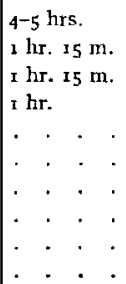 & 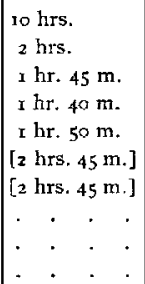 & 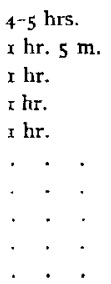 \\
\hline
\end{tabular}

1 The times enclosed in brackets refer to individual cases, and are not averages. The Ambiystoma egg, in the instance recorded, happened to have a quicker rhythm than the majority, and the Diemyctylus egg a slower rhythm. 
Each egg, as a rule, possesses an individual rhythm of cell-division, and the time intervals between the different sets of furrows are substantially the same in the same egg. There is, however, considerable variation between these rhythms in different eggs. We have, for example, observed the fourth set of furrows in an Amblystoma egg follow the third set in one hour and thirty minutes, while in another egg from the same mother the fourth set appeared only after an interval of two hours and forty-five minutes.

Making all due allowance, however, for this asynchronism, one fact stands out prominently in the table above. This is the fact that the inter-cleavage periods in the Urodelan eggs are much longer than the corresponding periods in the Anuran eggs. This difference does not depend upon the size of the egg. The small egg of the newt and the large egg of Amblystoma have practically the same rapidity of cell-division. The egg of Rana, on the other hand, which is considerably larger than the egg of the newt, divides much more speedily than the latter. We see no escape, therefore, from the conclusion that in this instance the rapidity of cell-division depends upon the innate and inherited tendencies of the cytoplasm and nucleus, rather than upon the size of the ovum. This view receives confirmation from the fact that the whole course of Urodelan and Anuran development is marked by a similar disparity in time. The formation and closure of the blastopore, the formation and closure of the neural folds, all take place more expeditiously in the Anuran than in the Urodelan embryos, while the Anuran tadpole frees itself from its gelatinous envelopes at a time when the Urodelan tadpole of the same age is destined to remain imprisoned for some ten days. The whole course of Urodelan development, therefore, from the entrance of the sperm (see Jordan, '93) to the release of the larva, is slower than that of the Anuran. This difference in rapidity of cell-division extends, as we have shown, to the earliest cleavage stages, and is foreshadowed in the pre-cleavage phenomena.

The quantity of yolk, however, exerts an unmistakable influence upon the speed with which furrows cut their way to the 
lower pole. In the largest eggs (Amblystoma) the vertical furrows consume nearly two hours in reaching the lower pole, while in the eggs of Dicmyctylus but little over an hour is needed for the same operation. The furrows in the newt and in the frog, on the contrary, advance towards the lower pole with about equal velocity, although, as we have stated, the inter-cleavage period is much the longer in the newt.

We have already indicated in a preliminary note the more important varieties of cleavage that we observed (Anat. Anz. VII, I 892). The proportion of eggs that swerved from the Amphibian "type" somewhat surprised us. In a batch of seventy-one frog eggs from one mother, for example, the first furrow divided all the eggs into nearly equal hemispheres. The second furrow cut the first at nearly right angles in the median line in sixty-nine eggs. In the other two eggs furrows appeared as shown in Fig. 5 ; these two eggs were isolated, and produced perfectly normal embryos. The next furrow was truly horizontal in only twenty-nine out of the sixty-nine eggs remaining; the other forty showed considerable variation. In some of these forty eggs equatorial furrows appeared in three quadrants, and a true vertical in the other quadrant (Figs. 2 and 8 ). In other eggs three cleavage planes were vertical and one horizontal (Fig. 26). In still other eggs the whole third set of furrows was vertical (Fig. 33).

This large proportion of variations from the normal is not uncommon, although in other batches of eggs a smaller number of variations was usually observed. In this respect there is considerable difference between eggs from different parents. Eggs from some parents showed far greater tendency to vary in the early stages than did others. In general, about one half of the eggs fail to form a true "first equatorial" plane in all four quadrants. Some of the more interesting of these deviations from the type are shown in Plate XXVI.

As the number of cells increases the cell-divisions become less synchronous. Some cells show a tendency to divide more rapidly than others, and consequently the furrows do not all appear simultaneously, but follow one after the other at perceptible intervals. In the fifth and sixth set of furrows, for 
example, there is a considerable lapse of time between the appearance of the first furrow in either set and the last furrow in the same set. Even in the third set we have observed so long a period as thirty minutes between the appearance of furrows in different quadrants (Figs. 12, 18). This tendency to divergent rhythm of cell-division brings it to pass that the last cell-division in one group falls nearer and nearer in time to the first cell-division in the next group, and in this way the distinction between "sets" of furrows is eventually lost. (See Figs. 4, I 3, I9, 28, 32, etc.) $U_{p}$ to the point to which we have been able to follow the cleavage, however (Amblystoma Ioth set), the general synchronism of division is maintained, and the furrows appear closely one after the other; then there is a marked pause before the next cell-division.

The question as to the "homology" of the third Teleostean furrow with the first equatorial furrow of the Amphibian egg has given rise to some difference of opinion. Some authors (Agassiz and Whitman, '84; Ziegler, $\mathbf{8 7}$ ) regard the first three furrows in the two groups as equivalent. Others (Rauber, '83; H. V. Wilson, '91) believe that the first equatorial furrow in the frog has been "lost" in the Teleost. Our observations on Amphibian cleavage bear, we think, directly on this point. We have found that the third set of furrows, which is usually horizontal, may sometimes be truly vertical in one, two, three, or even all four quadrants. (See Figs. 2, 8, 26, 33, etc.) That in these cases there is any "loss " or "dropping out " of furrows is obviously absurd, especially since the third set, when thus irregular, appears simultaneously with the "normal equatorial" of other eggs from the same parent. Now, since the third set of furrows in the Amphibia is sometimes truly vertical, there is no occasion for surprise that the third set in the Teleost egg is normally vertical. To speak of any "loss" of the third set of furrows in Teleosts, seems not only vague but meaningless. It is not at all remarkable that the spindles, under the different conditions prevailing in the Teleostean egg should take up a position different from that taken in the Amphibian egg. In the Amphibian egg itself, as we have shown, they are free to take a variety of positions even at the third division. 
All of our observations tend to emphasize the fact that great variation is a frequent occurrence in the early cleavage stages of the Amphibian egg. We have found irregularity to be the rule, regularity the exception. The appearance of the fourth set of furrows almost invariably marks the end of any constancy whatever in the relative position of the blastomeres. (See e.g., Figs. 3, 4, 7, 13, 19, 24, 28, 32.) The interesting condition discovered by Roux ('83) in the eggs of Rana esculenta, which enabled him to distinguish right and left sides in the sixteen-cell stage, we have not met with in any of the eggs we have examined.

We can, furthermore, attach no great importance to the existence of the Polfucht as formulated by Rauber ('83). It is generally true, we admit, that the furrows do not pass through a common point on the upper pole of the egg, but occasionally they do (Fig. I 5). We believe, consequently, that it is premature to formulate such a statement as that the furrows "alle suchen den Pol zu vermeiden." The furrows do not "avoid" the pole; but the mechanical cell-stresses are rarely so adjusted that the furrows intersect at the pole. There seems no need for a special term - Polflucht - to express this fact, since the "shunning" of the pole can hardly be a matter of primary significance.

Some of our observations bear indirectly upon the question of the relation of the first cleavage plane to the anteroposterior axis of the embryo. In the frog, as shown by the researches of Newport, Roux, and others, the first cleavage plane coincides with this axis; in Diemyctylus (Jordan, '93) and in Triton (Hertwig, '92), on the other hand, the first cleavage plane is at right angles to the axis. Our observations seem to indicate that this coincidence of the antero-posterior axis with one of the first two planes of division, is apparent rather than real. If such coincidence have any morphological meaning whatever, it must be in this way, that the derivatives of the cells on the right side of the first or second plane go to form the cells on the right side of the embryo. Our observations demonstrate, however, that the first and second cleavage planes undergo, even in the earliest stages, extensive torsion. Figs. 19, 
20,28 , for example, show that cells originally to one side of the mid-line have been so shifted by the stresses of cell-division as to lie unmistakably on the opposite side. Everything indicates that the extent of this shifting increases greatly in later stages. It is, of course, open to any one to suppose that the cells thus driven out of their original position regain this position later on. The probabilities against such an occurrence, however, seem to us so great that we feel justified in considering that the burden of proof rests on those who would maintain that this readjustment takes place. It seems to us a more reasonable supposition that the direction of the early cleavage planes and the embryonic axes have no vital connection, and that the coincidence, where it exists, is in itself of no fundamental significance.

It seems to be unnecessary to dwell here upon the question of cell homologies. Reference to our figures will show abundantly that the derivatives of equivalent quadrants do not hold similar positions. There exists in this respect a fundamental difference between these vertebrates and certain invertebrate groups, notably the annelids. In the amphibia, the more detailed the study, the more frequent and radical appear the cleavage variations, while in the annelids, as Wilson ('92) expresses it, "the cleavage of the ovum takes place with a precision and regularity which oft-repeated study only renders more striking and wonderful."

The Universtty of Chicago, March, I893. 


\section{PAPERS REFERRED TO.}

'84 Agassiz and Whitman, C. O. On the development of some Pelagic Fish Eggs. Proc. Amer. Acad. Arts and Sciences, xx. I 884.

'80 Clarke, S. F. Development of Amblystoma punctatum. Studies from the Biol. Lab. of Johns Hopkins Univ., ii. 1880 .

'92 Hertwig, O. Aeltere und neuere Entwickelungs-Theorieen. Berlin, 1892.

'93 Jordan, Edwin O. The Habits and Development of the Newt. Jour. Morph., viii. I 893 .

'83 Rauber. Neue Grundlegungen zur Kenntniss der Zelle. Morph. Jahrb. 1883.

'83 Roux, W. Ueber die Zeit der Bestimmung der Hauptrichtungen des Froschembryo. Leipzig. 1883 .

'92 Wilson, E. B. The Cell-Lineage of Nereis. Jour. Morph., I 892.

'91 Wilson, H. V. The Embryology of the Sea Bass (Serranus atrarius). Bull. U. S. Fish Comm., ix.

'87 Zregler, E. Die Entstehung des Blutes bei Knochenfischenembryonen. Arch. f. Mikr. Anat. 1887. 


\section{PLATE XXVI.}

In all the figures the continuous black lines represent the first cleavage plane, the broken lines the second, the blue the third, the red the fourth, the dotted lines the ffth. In most cases the precise time at which each furrow appeared is recorded on the figure.

Figs. I-IO represent eggs of Rana ; Figs. 11-15, Bufo; Figs. 16-24, Diemyc. tylus; Figs. 25-33, Amblystoma.

FIGS. I-4 represent successive stages of one egg viewed from the upper pole.

FIGs. 5 and 10, respectively, top and bottom views of one egg.

Figs. 6 and 7 , successive stages of one egg from upper pole.

FIG. 8. Upper pole; fourth set of cleavage planes just appeared.

FIG. 9. Upper pole; fourth set of cleavage planes just appeared.

FIGS. II-I3. Successive stages of one egg ; upper pole.

FIG. I4. Lower pole of egg shown in Fig. I3.

FIG. I 5. Upper pole showing conformity to diagram type of cleavage.

FIGS. 16-I9. Successive stages of cleavage of one egg showing remarkable irregularity. A normal embryo was formed from this egg!

FIG. 20. Upper pole showing great distortion of first cleavage planes.

Figs. 21-24. Successive stages of one egg; upper pole.

FIGS. 25-28. Successive stages of one egg; upper pole.

Figs. 29-32. Successive stages of one egg; upper pole.

FIG. 33. The central figure represents the upper pole of the egg, the surrounding figures are side views of the same egg. To each furrow is afixed a recognition number. 